УДК $657: 330.341 .1$

DOI: $10.15673 /$ fie.v10i2.960

\author{
Драбовський А.Г. \\ доктор економічних наук, професор \\ кафедра маркетингу та підприємництва \\ E-mail: rdag@vki.vin.ua
}

Іванюта П.В.

доктор наук з державного управління, доцент кафедра менеджменту

E-mail: ur6hdc@gmail.com

Петренко M.I.

доктор економічних наук, професор

кафедра фрінансів, обліку і аналізу

Вінницький кооперативний інститут

вул. Академіка Янгеля, 59, м. Вінниця, 21009

E-mail: seljony@gmail.com

\title{
РЕІНЖИНІРИНГ БІЗНЕС-ПРОЦЕСІВ ЯК НАПРЯМ УСПІШНОГО РОЗВИТКУ ДІЯЛЬНОСТІ ПІДПРИЕМСТВ
}

\begin{abstract}
У статті розкрита сутність реінжинірингу бізнес-процесів, що полягає у забезпеченні високої ефективності діяльності підприємства, і спрямоване на задоволення потреб споживачів. Слід зазначити, що необхідність проведення реінжинірингу для кожного підприємства полягає у забезпеченні безперебійності процесів виробництва і реалізації продукції, які характеризуються своєчасним надходженням сировини і матеріалів, підготовки і запуску технологічного обладнання щодо випуску напівфрабрикатів і виробів, сприяння тісному взаємозв'язку цехів, ліній та дільниць для кращого та неухильного виконання своїх функцій і завдань, пов'язаних з повним операційним циклом підприємства та ін. Поряд $з$ цим також розкриті основні поняття та надана класифікація бізнес-процесів. Тобто, впровадження реінжинірингу на підприємстві спрямовано на підвищення ефективності і результативності його діяльності шляхом своєчасного постачання продукції споживачам.
\end{abstract}

Ключові слова: реінжиніринг, бізнес-процеси, підприємство, організаційна структура, продукція, споживач.

This work is licensed under a Creative Commons Attribution 4.0 International License http://creativecommons.org/licenses/by/4.0/

Постановка проблеми та її зв'язок з важливими науковими та практичними завданнями. Необхідність реінжинірингу полягає у тому, що кожне підприємство зазнає відчутних змін у своїй діяльності, які безперервно пов'язані з оновленням i удосконаленням роботи цехів, дільниць та ланок, i спрямовані на досягнення ефективності господарської діяльності.

Безперервні та досить істотні зміни у технологіях, ринках збуту і потребах клієнтів стали звичайним явищем, і підприємства, прагнучи вижити в сучасних ринкових умовах, змушені безперервно перебудовувати свою стратегію і тактику. Рішенням проблеми є зміна базових принципів організації операційної (виробничої) діяльності та перехід до орієнтації не на функції управління керівниками підприємством і сферами його діяльності, а на процеси, які відбуваються всередині підприємства. Для цього розкривається зарубіжний і вітчизняний досвід процесів операційної діяльності підприємств, їх розвитку та удосконалення, в результаті чого сформувався процес під назвою «реінжиніринг», що взагалі означає залучення у діяльність підприємства передового досвіду й поліпшених технологічних операцій. А на науковому рівні серед вчених проводилися такі дослідження, що стосуються реінжинірингу, які заклю- чалися у напрямах розвитку виробничих процесів, підвищенні ефективності технологічних операцій господарської та підприємницької діяльності, встановленню чіткої ієрархії системи управління на підприємствах поряд з назначеними функціями, пошуку резервів щодо підвищення обсягів виробництва продукції і зниження витрат. Але до сих пір недостатньо розглянуті та досліджені явища своєчасності виконання функцій і завдань при веденні виробничого процесу, умови і напрямки забезпечення взаємозв'язків між структурними одиницями при уникненні дублювань, збоїв та незлагодженостей у їх діяльності та функціонуванні, такі як цехи, відділки, ланки, дільниці та ін., а також здатність випускати, надавати і реалізовувати вироби і продукцію у встановлені та очікувані споживачами терміни. Тут подальше дослідження реінжинірингу буде більш доцільним за рахунок формування єдиного комплексу процесів, що матимуть кращі особливості технологічних процесів на підприємстві, а також виділення напрямів оптимального й раціонального спрямування ресурсів, які перетворюватимуться у вироби й продукцію 3 врахуванням просторових і часових параметрів, своєчасній доставці їх на ринки збуту i продаж споживачам. 
Зазначаючи практичний зарубіжний і вітчизняний досвід, наукові праці вчених та напрями подальших досліджень у цій статті підтверджують актуальність теми дослідження, які спрямовані на перетворення системи управління підприємства, та реорганізацію операційних циклів у ньому - відповідно до більшої ефективності, віддачі і досконалості випуску виробів та продукції.

Аналіз останніх публікацій по проблемі. Реінжиніринг бізнес-процесів розглядається як новітній і досконалий метод управління, що спрямований на поліпшення сфер діяльності підприємства. А до вчених, які досліджували реінжиніринг, відносяться Андерсен Б., Блінов А.О., Брімсон Дж., Виноградова О., Попов В., Робсон М., Уллах Б., Хаммер М, Чампі Дж. Вітчизняна вчена О. Виноградова обгрунтувала реінжиніринг бізнес-процесів як напрям щодо перетворення системи й функцій управління на підприємстві. Російські вчені А.О. Блінов та В.М. Попов під реінжинірингом визначає пристосування функцій і процесів, які містяться всередині системи управління на підприємстві, до сучасних вимог ринкової економіки, а також підвищення ефективності підприємницької діяльності. Вчений Майкл Хаммер вперше сформував термін реінжиніринг у зв'язку 3 необхідністю дослідження процесів удосконалення підприємницької діяльності з огляду на максимальну продуктивність бізнес-процесів, а вчений Дж. Чампі у своїх наукових працях вперше здійснив розповсюдження цього терміну, коли досліджував процеси перетворення й удосконалення підприємствами власної матеріально-технологічної бази, системи управління, здійснення ними виробничих операцій. А Дж. Брімсон розглядає реінжиніринг як спосіб виконання стратегії розвитку підприємства, де перетворення технологічного циклу в ньому супроводжується етапами життєвого циклу - починаючи від проектування виробу і закінчуючи впровадження поліпшень і удосконалень у виробничій системі підприємства поряд із випуском готового виробу чи продукції. Науковець Б. Андерсен до реінжинірингу відносить напрями удосконалення операційних (виробничих) процесів на підприємстві разом із визначенням пріоритетів розвитку, встановлення цілей підприємницької діяльності і засобів їх досягнення, в т.ч. за рахунок розробки і поетапної реалізації програм і прогнозів для цього. А науковці М. Робсон та Б. Уллах під реінжинірингом розглядають удосконалення операційної (виробничої) діяльності підприємства й управлінських функцій в ньому шляхом перетворення їх у бізнес-процеси.

Але слід зазначити, що саме реінжиніринг, як і бізнес-процеси, здебільшого розглядалися у більшій мірі лише практиками, які спеціалізуються на управлінні господарською діяльністю підприємства. Але, незважаючи на це, подальшого дослідження потребує обгрунтування необхідності реінжинірингу бізнес-процесів на підприємстві та етапів їх впровадження.

Формулювання цілей дослідження полягає у розкритті як самих бізнес-процесів, так і реінжині- рингу, а також у визначенні його сутності у діяльності підприємств на сучасному етапі ринкових відносин та звернення особливої уваги щодо поліпшення й удосконалення господарської діяльності для задоволення потреб споживачів. Для досягнення встановленої мети необхідно виконати такі завдання:

- обгрунтувати сутність реінжинірингу на сучасному етапі розвитку підприємств;

- розкриття переходу від функціонального до процесного підходу як необхідності удосконалення системи управління на підприємстві згідно сучасних вимог ринкової економіки;

- дослідження бізнес-процесів та їх ролі у досягненні очікуваних підприємством результатів.

Виклад основних результатів та їх обгрунтування. Реінжиніринг - це фундаментальне переосмислення і радикальне перепроектування процесів діяльності всередині підприємства для досягнення його максимальної економічної ефективності за техніко-економічними, фінансовими та іншими показниками, а також такими критеріями, як вартість, якість, сервіс, темпи зростання продажу та прибутковості [1, c. 14].

Реінжиніринг бізнес-процесів - це створення абсолютно нових і більш ефективних бізнес-процесів всередині підприємства у порівнянні з минулими. Він являє собою перетворення методів, функцій і механізмів управління у виробничих підрозділах і структурних одиницях, як цехи, відділки, дільниці усередині звичайної організаційної структури підприємства, зокрема там, де відбуваються операційні (виробничі) процеси, які призводять до випуску виробів та продукції разом із своєчасною відправкою їх споживачам $[5$, c. 28$]$.

Термін «реінжиніринг» означає поліпшення та удосконалення існуючих конструктивних виробів, технічне обслуговування або ремонт. Тобто реінжиніринг - це оригінальний процес визначення, розробки виробу чи продукту та їх реалізації за рахунок поліпшеної на підприємстві виробничої системи - згідно 3 системним підходом. Тут також доцільно зазначити про зворотній інжиніринг, або зворотня інженерія, - як процес, де у всередині виробничої системи підприємства виріб чи продукт розглядається з метою визначення, аналізу та оцінки їх споживчих властивостей або на рівні технологічних специфікацій $[8$, c. 264].

Реінжиніринг $\epsilon$ інструментом операційних процесів підприємства, який став популярним у кінці 1980 - початку 1990-х років. Він спрямований на скорочення витрат і в той же час підвищення продуктивності праці та задоволення потреб споживачів за рахунок своєчасної поставки продукту або його досконалого обслуговування. Концепцією, що лежить в основі реінжинірингу, $є$ необхідність підтримання конкурентоспроможності, якості, продуктивності та інших складових діяльності підприємства. До концепції реінжинірингової моделі входить оптимізація витрат на всі види ресурсів і персонал, формування команди та «початок із нуля». Недоліком цього методу є модернізація, яка є дорогим процесом, а також 
консультаційні послуги ззовні, які потребують значних витрат [6, с. 55].

Але новизна бізнес-інжинірингу полягає у детальному і формалізованому описуванні складових управління діяльністю підприємства. А це стало можливим завдяки тому, що виникають стандарти опису складових управління згідно з організаційною структурою підприємства та тих процесів діяльності, що відбуваються всередині підприємства. Реінжиніринг бізнес-процесів на підприємстві головним чином передбачає застосування комп'ютерних технологій для спрощення і водночас удосконалення процесів прийняття управлінських рішень шляхом їх підтримки через формування баз даних, їх збереження, систематизацію, обробку і подання необхідної інформації керівникам. Тобто, всі бізнес-процеси, які є в системі управління на підприємстві, містять у собі такі функціональні блоки управлінської діяльності: стратегію, оргструктуру, логістику, фінанси. I ці блоки надають можливість керівникам, які мають достатні знання i досвід процесу реалізації управлінських рішень на основі процесного підходу, встановлювати довгострокові цілі та формувати стратегічні напрями діяльності підприємства.

Відповідно до матеріалів Європейської економічної комісії ООН (табл. 1), реінжиніринг у залежності від процесного підходу поділяється на базові види спеціалізованих робіт, починаючи зі визначенням та реалізації заходів, а також консультацій щодо поліпшення виробничих процесів, тобто основної діяльності підприємства, продовжуючи управлінням постачанням, випуском перших зразків виробу чи продукту, їх технічним доопрацюванням і поліпшенням, та закінчуючи інтегрованим комплексним інжинірингом, тобто повністю сформованою продукцією чи товаром, який спрямовується на реалізацію на зовнішні ринки чи відправки до замовника.

Таблиця 1

Розкриття сутності процесу реінжинірингу*

\begin{tabular}{|c|c|}
\hline Реінжиніринг & Зміст і характеристика \\
\hline Консультаційний & $\begin{array}{l}\text { Проектування, авторський нагляд, планування та підготовка } \\
\text { до процесу виробництва продукції, тобто етапи НДР і ДКР } \\
\text { (наприклад, підтримка прийняття рішень, сітьові графіки), } \\
\text { контроль за виконанням вимог стандартів, нормативів, тех- } \\
\text { нічної та проектно-кошторисної документації (технічне } \\
\text { замовлення), випробування, експертиза, консультації }\end{array}$ \\
\hline Технологічний & $\begin{array}{l}\text { Передача технологій для операційної (виробничої) діяльності } \\
\text { підприємства та їх монтажу, передача ліцензій, досвіду щодо } \\
\text { експлуатації цих технологій, надання консультаційних пос- } \\
\text { луг та ін. }\end{array}$ \\
\hline $\begin{array}{l}\text { Підготовка до процесу виробництва } \\
\text { і початок виробничого процесу }\end{array}$ & $\begin{array}{l}\text { Проектування, постачання технологічного обладнання та } \\
\text { його монтаж }\end{array}$ \\
\hline Комплексний & $\begin{array}{l}\text { Проектування, постачання технологічного обладнання. На- } \\
\text { станови щодо дотримання стандартів, нормативів, технічної } \\
\text { та проектно-кошторисної документації, відправка продукції } \\
\text { або товару замовникам або на зовнішні ринки. }\end{array}$ \\
\hline $\begin{array}{l}\text { Технічна взаємодія, доопрацювання, } \\
\text { поліпшення, удосконалення }\end{array}$ & $\begin{array}{l}\text { Послуга або ряд послуг, що надаються в ході реалізації про- } \\
\text { екту і (або) після його закінчення для освоєння переданих } \\
\text { технологій, обладнання, здійснення авторського нагляду і } \\
\text { навчання кадрів }\end{array}$ \\
\hline
\end{tabular}

*Розроблено авторами на основі [7, с. 33 - 36]

Процесний підхід згідно з Міжнародним стандартом ISO 9001 : 2009 означає застосовування в межах організації системи процесів разом 3 їх ідентифікуванням і взаємодіями, а також керуванням ними для одержання бажаного результату. Перевага процесного підходу - неперервний контроль зв'язків окремих процесів у межах системи процесів, а також їх поєднань і взаємодій $[11$, с. 6]. Застосовуючи такий підхід у межах системи управління, яка є на підприємстві, особливу увагу приділяють:

1) розумінню та виконанню вимог;

2) потребі розглядати процеси 3 погляду створювання додаткових цінностей;

3) отриманню результатів функціонування процесу та досягненню результативності;

4) постійному поліпшенню процесів на основі об’єктивного вимірювання.

Основою для впровадження реінжинірингубізнес-процесів у практику підприємств є Європей- ська модель ділової досконалості, що отримала назву «Модель ділової досконалості EFQM», яка створена у 1991 р [9, с. 5 - 8]. Модель EFQМ має такі цілі й завдання:

- стимулювання європейських підприємств i організацій до проведення заходів, направлених на досягнення ділової досконалості, тобто на підвищення рівня задоволеності споживачів і власних працівників, а також на отримання вищих ділових результатів і позитивний вплив на суспільство;

- надання підтримки менеджерам європейських організацій у прискореному впровадженні принципів як вирішального чинника в досягненні глобальної конкурентоспроможності.

Європейський фонд управління якістю є розробником схеми, що має назву «модель досконалості» (рис. 1), де процентне співвідношення показує відносну важливість кожного 3 критеріїв, що сприяють досягненню підприємствами від своєї діяльності 
економічної ефективності за рахунок застосування підходів реінжинірингу бізнес-процесів, а також їх результативності. Ця модель складається 3 дев'яти критеріїв, кожен з яких характеризується відповідними підкритеріями. Модель ділиться на дві групи критеріїв: критерії підходу і критерії результатів.

Навчання та нововведення

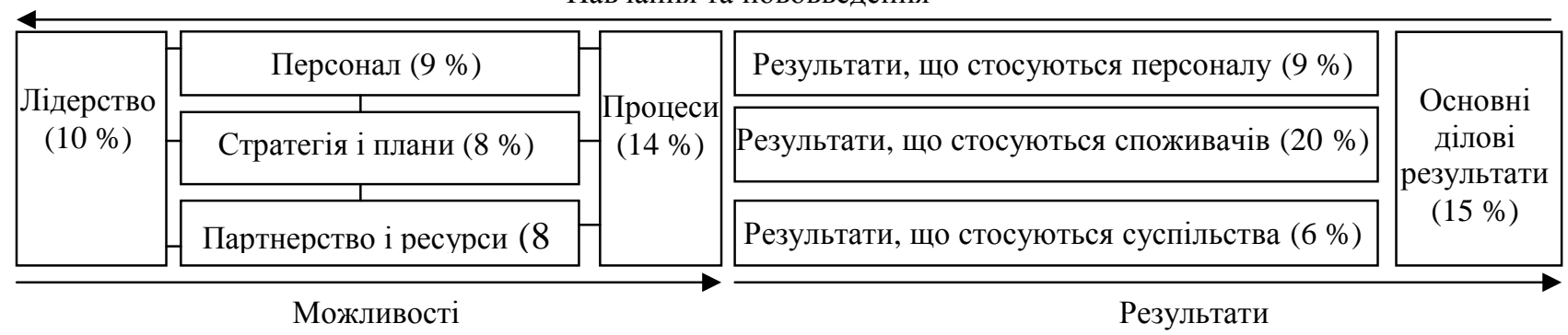

Рис. 1. Модель досконалості Європейського фонду управління якістю [9, с. 9]

До критеріїв підходу належать такі:

- лідерство (формування місії, пропозицій, пріоритетів, точок зору щодо прийняття рішень; участь у розробці, впровадженні та постійному удосконаленні систем управління; співробітництво із споживачами, постійними клієнтами, контрагентами і суспільством; залучення працівників, їх підтримка i визнання професійного рівня);

- політика, стратегія і плани (обгрунтування політики і стратегї нинішніх і майбутніх потреб та очікувань зацікавлених сторін - як виробників, так і споживачів продукції; обгрунтування політики і стратегії на інформації, що отримана в результаті оцінки ефективності, досліджень, навчання, творчої діяльності; розробка, перегляд і актуалізація політики і стратегіï, їх розповсюдження на основні процеси, а також розкриття інформації про ступінь їх впровадження i реалізацію);

- персонал (планування, управління і удосконалення навиків працівників; визначення, розвиток і інші заходи, спрямовані на постійне підвищення знань та компетенції працівників; їх залучення у процес удосконалення діяльності підприємства і передавання їм повноважень; посилення діалогів між керівництвом підприємства і працівниками; стимулювання і визнання професійного рівня працівників і їх заохочення);

- партнерство і ресурси (управління зовнішніми партнерськими зв'язками, фінансовими ресурсами, матеріальними ресурсами, інформаційними та інтелектуальними ресурсами, нерухомістю та обладнанням, технологіями);

- процеси (систематична розробка процесів i управління ними; удосконалення процесів з використанням інновацій для повного задоволення потреб споживачів і інших зацікавлених сторін для формування і підтримання фундаментальних основ; проектування і розробка продукції та послуг на основі потреб і очікувань споживачів; виробництво, збут і обслуговування продукції та послуг; управління зв'язками зі споживачами та їх розширення).

До результативних критеріїв відносяться:

- результати, що стосуються споживачів (показники рівня сприйняття продукції та послуг споживачами, їх попит; показники ефективності виробничого процесу і реалізації продукції за оцінками споживачів);
- результати, що стосуються персоналу (показники рівня сприйняття продукції та послуг працівниками підприємства, їх пропозиція; показники ефективності виробничого процесу і реалізації продукції за оцінками виробників);

- результати, що стосуються суспільства (показники рівня сприйняття продукції та послуг широкими верствами населення, їх частка на ринку; показники ефективності виробничого процесу і реалізації продукції за оцінками населення);

- основні ділові результати (зовнішні показники основної, допоміжної та підсобної діяльності; показники ефективності виробничого процесу і реалізації продукції за загальними (комплексними) оцінками) $[9$, с. 5 - 7].

А метод реінжинірингу базується на адаптації технологій та менеджменту до зміни існуючих систем, організацій, процесів і продукції, що є на підприємстві, 3 метою зробити їх більш ефективними, дієвими. Він спрямований на зміну потенціалу у всіх бізнес-, або організаційних процесах, включаючи процес формування системи самого циклу [11]. Система управління реінжинірингу може бути визначена як вивчення, дослідження, збір, зміна внутрішніх механізмів, функціональність існуючої системи управління процесами і практики в організації, з метою відновлення їх у новій формі і з новими можливостями адаптуватись до вимог конкурентоспроможності, але без зміни стратегічних цілей.

Одне із базових понять реінжинірингу - бізнес-процес. А бізнес-процес - це потік роботи, що переходить від одного об' єкту діяльності до іншого, а якщо указувати на великі процеси, такі як підприємство - то від одного підрозділу (відділу, цеху, ланки, дільниці) до іншого. Процеси можна описати на різних рівнях, але вони завжди мають початок, певну кількість кроків і чітко визначений результат.

А підприємства у залежності від власної організаційної структури повинні розробити власні етапи щодо реінжинірингу бізнес-процесів, тому що це сприятиме більш глибокому розумінню власної ситуації і окреслить можливі перспективи щодо ефективності діяльності за техніко-економічними та фінансовими показниками. Підприємствам доцільно впроваджувати реінжиніринг не лише у своїх підрозділах виробництва або реалізації продукції, а й у всіх сферах діяльності - згідно існуючої організаційної струк- 
тури, покладених функцій управління, завдань і роз- порядків (рис. 2).

\begin{tabular}{|c|c|c|c|}
\hline $\begin{array}{l}\text { Діяльність } \\
\text { підприємства }\end{array}$ & $\begin{array}{c}\text { Суб’єкт управління (керівники підпри- } \\
\text { ємства, підрозділів, ланок, цехів, діль- } \\
\text { ниць і відділів) }\end{array}$ & \begin{tabular}{l|l}
+ \\
\end{tabular} & $\begin{array}{c}\text { Початок і закінчення } \\
\text { бізнес-процесів }\end{array}$ \\
\hline
\end{tabular}

До важливих бізнес-процесів підприємства відносяться:

- розробка виробу і продукції: від кон'юнктури ринку і запитів клієнтів на виріб чи продукт до створення конструкторської документації;

- закупівля товарно-матеріальних цінностей і матеріальних ресурсів: від вибору постачальника до направлення їх у виробничий процес.

Рис. 2. Схематичне відображення бізнес-процесів та їх сутності у веденні операційної (виробничої) діяльності підприємства [10, с. 129]

Виходячи з наведеної типології опису бізнес- різних груп процесів (див. рис. 3). процесів, потрібно більш детально навести складові

Класифікація бізнес-процесів підприсмства
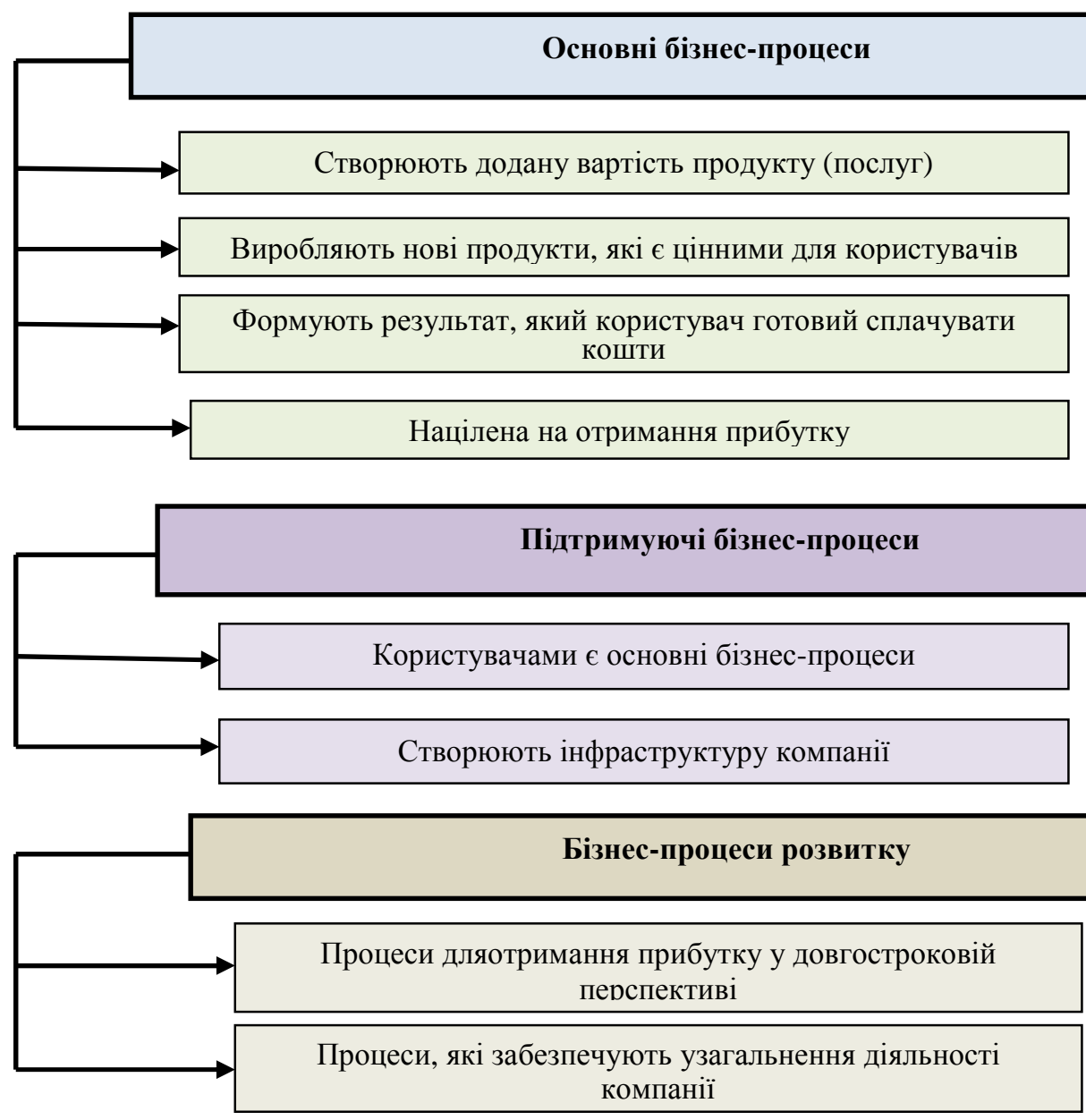

Процеси управління

Націлені на управління діяльністю компанії

Рис. 3. Структурна класифікація бізнес-процесів підприємства відповідно до вимог міжнародного стандарту ISO 9001 : 2009*

* розроблено авторами на основі [11, с. 15-21] 
У сучасних ринкових умовах бізнес-процеси всередині підприємства у першу чергу спрямовані на досягнення максимальної ефективності і результативності його діяльності шляхом перетікання функцій управління до процесів діяльності, пов'язаних із створенням виробу чи продукту з одного підрозділу в інший для забезпечення своєчасності виконання замовлень, з меншою кількістю помилок і недоліків.

Наступним чином реінжиніринг бізнеспроцесів повинен сприяти більш повному збору інформації про ринкові сегменти, врегульовувати конфлікти між підрозділами, а етапи процесів діяльності, які відбуватимуться всередині підприємства, будуть більш передбачуваними і меншим чином призводитимуть до затримок при виконанні господарських завдань кожним підрозділом і сприятимуть більшій компетентності та оперативності керівників у процесі прийняття управлінських рішень.

Для здійснення більш глибокого аналізу діяльності підприємства доцільно розробити типову модель бізнес-процесів. На рис. 4 наведений приклад моделі бізнес-процесу вищого управлінського рівня підприємства, яке займається виробництвом комбікормів, виконаний у стандарті SADT/IDEF0.

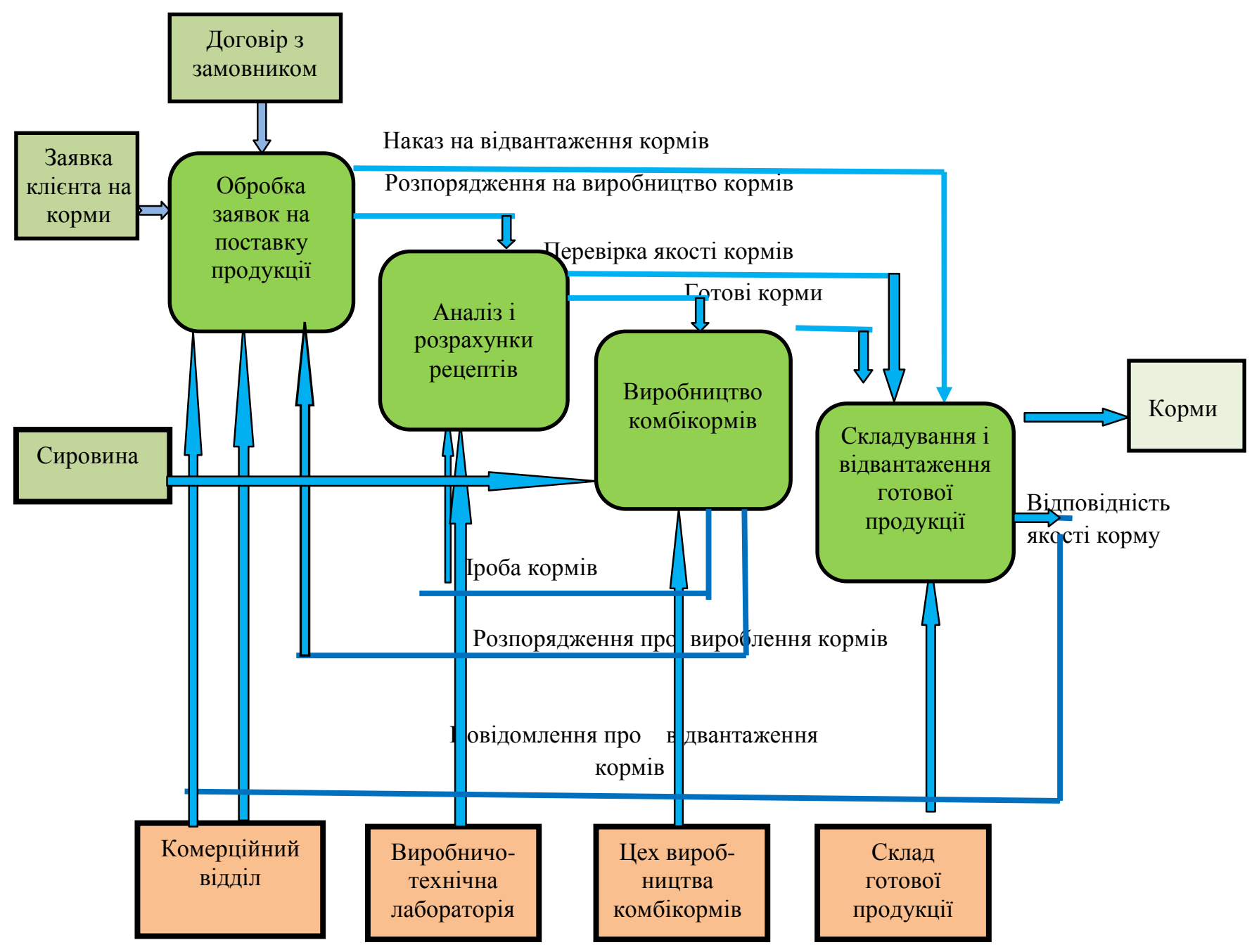

Рис. 4. Приклад моделі бізнес-процесу підприсмства з виробництва комбікормів * розроблено авторами на основі [10, с. 152]

Ця модель бізнес-процесу показує чіткий взаємозв' язок між підрозділами підприємства, послідовність виконання завдань і розпоряджень керівників, а також матеріальні й інформаційні потоки, що дозволяє виявити вузькі і неоптимальні сторони бізнеспроцесу, включаючи розриви в матеріальних потоках та інформації.

На нашу думку, реінжиніринг являє собою комплекс заходів щодо модернізації та осучаснення виробничої системи, існуючому на підприємстві, шляхом перетворення функцій управління, які має апарат управління, у бізнес-процеси, тобто процеси управління на місцях у виробничих підрозділах підприємства. Тому що саме бізнес-процеси, які містяться у системі управління разом із такими структурними одиницями, як цехи, відділки, дільниці, ланки та ін. означають локалізовану на них управлінську діяльність. 
В результаті чого децентралізованим способом оперативно приймаються управлінські рішення, забезпечується своєчасність технологічних операцій, досягається максимальний економічний ефект, заощаджуються ресурси і контролюються витрати для виробництва продукції і виробів.

Звідси випливає, що застосування реінжинірингу бізнес-процесів на підприємстві має взагалі чотири етапи:

1. Розробка майбутнього проекту підприємства - специфікація основних цілей підприємства, виходячи з їі стратегії, потреб клієнтів, загального рівня та ситуації перебування підприємницької діяльності в галузі.

2. Створення існуючої (теперішньої) моделі підприємства (зворотнім чи ретроспективним інжинірингом). На цьому етапі керівники підрозділів з участю розробників інформаційних систем повинні створити детальний опис існуючого підприємства його організаційної структури, виробничої системи, і на основі них ідентифікувати і документувати основні бізнес-процеси, оцінити їх ефективність.

3. Розробка нового бізнесу:

- Перепроектування бізнес-процесів. Створення більш ефективних робочих процедур (елементарних завдань, 3 яких будуються бізнес-процеси), визначення способів використання інформаційних технологій, ідентифікація необхідних змін у роботі персоналу.

- Розробка бізнес-процесу для підприємства на рівні нинішнього працюючого персоналу. Тут проектуються різні види робіт, готується система мотивації, організовуються команди 3 виконання робіт i групи підтримки якості, створюються програми підготовки фахівців та ін.

- Розробка інформаційних систем і впровадження комп'ютерних технологій для підтримки прийняття рішень, затверджених керівництвом. На цьому етапі визначаються наявні ресурси (устаткування, програмне забезпечення) і реалізується спеціалізована інформаційна система (або системи) підприємства.

4. Впровадження заходів, які передують проектуванню бізнес-процесів. Інтеграція і тестування розроблених процесів, а також застосування підтримуючих інформаційних систем, навчання співробітників, установка спеціалізованого програмного продукту, модернізація процесу діяльності підприємства.

Функціонування реінжинірингу у багатьох підприємствах призвело до позитивних змін, які відобразилися на досягненні ефективності операційного (виробничого) процесу, важливих показників, як економічність, окупність, рентабельність, конкурентоспроможність, своєчасність та ін. Наприклад, такі вінницькі підприємства, як ПрАТ «Володарка» і ПАТ «Маяк» при впровадженні реінжинірингу досягли збільшення доходів від реалізації продукції за рахунок оптимізації структури управління, встановленні інформаційних технологій, оптимізації витрат за рахунок застосування методів бюджетування як способу реінжинірингу, що забезпечило суттєву економію витрат на випуск продукції та збільшення обсягів продаж на основі іншого способу реінжинірингу, як контроль якості дії технологічного циклу у операційній діяльності. Тут також доцільно вказати, що результативність реінжинірингу на цих підприємствах визначалася шляхом постійного порівняння у їх структурних одиницях планових показників 3 фактичними даними, аналізування і усунення відхилень на місцях, що призвело до підсилення сприятливих й зменшення несприятливих тенденцій, які виявилися у кінці місяця, кварталу, року.

Отже, наукова і практична цінність здійснення реінжинірингу на підприємствах полягає у тому, що досліджуються і аналізуються управлінська діяльність всередині структурних одиниць підприємства 3 орієнтацією на досягнення важливих критеріїв, як збільшення обсягів діяльності й дохідності, а також темпів їх наростання, економність засобів і ресурсів за рахунок раціоналізації та оптимізації операційних (виробничих) процесів, координація і посилення взаємозв'язків структурних одиниць між собою для виконання внутрішньовиробничих завдань 3 метою своєчасного постачання споживачів продукцією і пошуку додаткових резервів для поліпшення й продуктивності технологічного циклу у сфері підприємницької діяльності.

Реінжиніринг операційних (виробничих) процесів являє собою безліч методик, які використовуються для перепроектування діяльності підприємства, що відповідають заданим стратегічним цілям. Ці методики включають: ня бізнесу;

1) покрокові процедури для перепроектуван-

2) систему ключових критеріїв, що описує перепроектування бізнесу;

3) евристичні та прагматичні рішення, що дозволяють 3'ясувати ступінь відповідності перепроектованого бізнесу заданим цілям.

На нашу думку, реінжиніринг бізнеспроцесів спрямований для поліпшення організаційної (виробничої) системи й технологічних циклів всередині підприємства на конкурентоспроможній основі. Тому з урахуванням досвіду вчених та дослідників, слід вважати, що термін «реінжиніринг» має комплексне поняття, тобто означає перебудову організаційної структури підприємства й системи його управління виробничими процесами у структурних одиницях, як цехи, відділки, ланки з метою отримання більшої ефективності, результативності та віддачі від основної діяльності за рахунок забезпечення своєчасності виконання замовлень споживачів й реалізації продукції на ринках.

Висновки та перспективи подальших досліджень. Авторське трактування терміну «реінжиніринг» $€$ таким, що він спрямований на поліпшення та 
удосконалення організаційної системи підприємства 3 метою досягнення більшої ефективності технікоекономічних, фінансових та інших показників діяльності підприємства, а також своєчасності виконання замовлень. Також автором доведено, що реінжиніринг $з$ точки зору замовника означає скорочення терміну виконання замовлення та відсутність при цьому додаткових формалізованих і дублюючих процедур, в результаті чого забезпечується своєчасне отримання товарів, робіт, послуг у супроводженні 3 необхідним обсягом часу. А з точки зору підприємства, - зменшуються додаткові витрати, підвищується ефективність, результативність, конкурентоспроможність його діяльності і також з'являється можливість завоювати більшу частку ринку.

Науковою новизною є визначення реінжинірингу як напряму переходу системи управління на підприємстві від функціонального підходу до процесного підходу, тобто, здійснення управління підприємницькою діяльністю на основі процесів, які відбуваються у таких структурних підприємствах, як цехи, відділки, дільниці - $з$ орієнтацією на попит продукції та виконання замовлень на неї. Теоретичне і практичне значення реінжинірингу полягає у вивченні та детальному дослідженні напрямів і шляхів удосконалення системи управління підприємницької діяльності - на основі виділення таких складових, як бізнеспроцеси і структурні одиниці. Далі вони характеризуються і обгрунтовуються за ступенями досягнення ефективності й результативності підприємницької діяльності за обсягами виробництва і реалізації продукції, поряд з тим визначається внесок кожного бізнес-процесу та структурної одиниці у виконанні стратегічних напрямів підприємства. Оскільки сучасний етап розвитку суспільства та ринкових відносин в економіці держав стрімко змінюються, а технічні засоби для здійснення виробничих процесів на підприємствах удосконалюються та модернізуються, існує перспектива подальшого дослідження реінжинірингу 3 метою пристосування до умов зовнішнього середовища та застосування зворотнього зв'язку для забезпечення постійної здатності задовольняти потреби споживачів.

\section{Література}

1. Хаммер М. Реинжениринг корпорации: Манифест революции в бизнесе. Reengineering the Corporation: A Manifesto for Business Revolution. / М. Хаммер, Дж. Чампи - М.: Издательство: Манн, Иванов и Фербер, 2007. - 288 c.

2. Современные бизнес-технологии: [учеб. пособие] / В.М. Попов, С.И. Ляпунов, В.В. Филиппов, Г.В. Медведев. - М.: КноРус, 2006. - 384 с.

3. Реинжиниринг бизнес-процессов: [учеб. пособие для студ. вузов] / под ред. А. О. Блинова. - М.: ЮНИТИ-ДАНА, 2010. - 343 с.

4. Бримсон, Джеймс. Стратегия реинжиниринга / Д. А. Бримсон // Менеджмент и менеджер. - 2007. № 5. - C. 4-10.

5. Андерсен Б. Бизнес процессы. Инструменты совершенствования / Андерсен Б. ; пер. с англ. С. В. Ариничева ; науч. ред. Ю. П. Адлер. - М.: РИА «Стандарты и качество», 2003. - 272 с.

6. Робсон М. Практическое руководство по реинжинирингу бизнес процессов / М. Робсон, Ф. Уллах ; пер. с англ. под ред. Н.Д. Эриашвили. - М.: Аудит, ЮНИТИ, 1997. - 224 с.

7. Антикризисный менеджмент: Тренинг-семинар. - Проект UKR/96/007 «Поддержка развития малых и средних предприятий в Украине» / Международный Центр Развития Предпринимательства и Менеджмента, Государственный комитет Украины по Развитию Предпринимательства, - Програма развития Организиции Обьединенных Наций. - Полтава, 1999. - 82 с.

8. Виноградова, О. Особливості моделювання бізнес-процесів організації на принципах реінжинірингу / О. Виноградова // Вісник Тернопільської академії народного господарства. - 2005. - № 2. - С. 263 - 270.

9. Конспект модели управления качеством / Украинская ассоциация качества. Межотраслевой центр качества «Прирост». - К., 2002. - 149 с.

10. 7 Нот менеджмента : настольная книга руководителя. - М.: ЭКСМО, 2007. - 828 с.

11. Система управління якістю. Вимоги (ISO 9001 : 2008, IDT): ДСТУ ISO 9001:2009. - [Чинний від 2010-01-01]. - К.: Держстандарт України, 2010. - 34 с. 
Драбовский А.Г.

доктор экономических наук, профессор кафредра маркетинга ипредприниммательства E-mail: rdag@vki.vin.ua
Иванюта П.В.

доктор наук по государственному управлению, доцент кафедра менеджмента

E-mail: ur6hdc@gmail.com

Петренко М.И.

доктор экономических наук, профессор кафредра фринансов, учета и анализа Винницкий кооперативный институт ул. Академика Янгеля, 59, г. Винница, 21009 E-mail: seljony@gmail.com

\section{РЕИНЖИНИРИНГ БИЗНЕС-ПРОЦЕССОВ В ОБЕСПЕЧЕНИИ ЭФФЕКТИВНОЙ ДЕЯТЕЛЬНОСТИ ПРЕДПРИЯТИЙ}

В статье раскрытая сущность реинжиниринга бизнес-процессов, что состоит в обеспечении высокой эфрфективности деятельности предприятия, направленное на удовлетворение потребностей покупателей. Следует обозначить, что необходимость проведения реинжиниринга для каждого предприятия состоит в обеспечении непрерывности процессов производства и реализации продукции, а именно: характеризующееся своевременным поступлением сырья и материалов; подготовки и запуска технологического оборудования к выпуску полуфабрикатов и изделий; способствование тесной взаимосвязи цехов, линий и участков для лучшего и неуклонного выполнения своих функций и задач, связанных с полным операционным циклом предприятия. Наряду с этим также раскрыты основные понятия и предоставленная классификация бизнес-процессов. То есть, внедрение реинжиниринга на предприятии способствует повышению эфффективности и результативности его деятельности путем своевременного снабжения продукции потребителям.

Ключевые слова: реинжиниринг, бизнес-процессы, предприятие, организационная структура, продукция, потребитель.

Drabovsky A.

Doctor of Economics, Professor Department of Marketing and Business E-mail: rdag@vki.vin.ua
Ivanyuta $\mathbf{P}$.

Doctor of Public Administration, Associate Professor Department of Management E-mail: ur6hdc@gmail.com

Petrenko M.

Doctor of Economics, Professor

Department of Financial, Accounting and Analyses

Vinnitsa Cooperative Institute

Akademyka Janghelja str.,59, Vinnitsa, Ukraine,21009

E-mail: seljony@gmail.com

\section{REENGINEERING OF BUSINESS PROCESSES IN PROVIDING EFFECTIVE ACTIVITY OF ENTERPRISES}

The article reveals the essence of reengineering of business processes, which is to ensure the high efficiency of the enterprise, and is aimed at satisfying the needs of consumers. It should be noted that the need for reengineering for each enterprise is to ensure the continuity of production and sales processes that are characterized by the timely receipt of raw materials and materials, the preparation and launch of process equipment for the production of semi-finished products and final production; promotion of close interconnection of workshops, lines and sections for better and consistent performance of their functions and tasks related to the full operational cycle of the enterprise, etc. At the same time, the basic concepts and the classification of business processes have also been revealed.

And the need to implement reengineering business processes into the practice of the company is associated with an increase in the efficiency and effectiveness of its activities - through the flow of management functions associated with the creation of an article or a product in one unit, and the transfer of it to another unit - to ensure timely carrying out of clients orders, with fewer errors, disadvantages, and unpredictable loss of resources. In the future, the reengineering of business processes will promote the interconnection between the divisions of the enterprise, ensuring the sequence of tasks and orders carrying 
out, as well as optimizing material and information flows in identifying the narrow and non-optimal sides of the business process.

Thus, the article reveals the necessity of reengineering to improve the management system in the enterprise by restructuring its organizational structure, increasing the efficiency of its activities, which consists in increasing the volume of activity and profitability, optimal use of methods and resources in technological processes, coordination and strengthening of interconnections of structural units among themselves for the implementation of home tasks with a view to timely supply products to the consumers.

Key words: reengineering, business process, enterprises, structure of organization, product, consumer.

\section{References}

1. Hammer, M., \& Champi, Dzh. (2007). Reinzheniring korporatsii: Manifest revolyutsii v biznese [Reengineering the Corporation: A Manifesto for Business Revolution]. M.: Izdatelstvo: Mann, Ivanov i Ferber. M.: KnoRus.

2. Popov, V. M., Lyapunov, S. I., Filippov, V. V., \& Medvedev, G. V. (2006). Sovremennyie biznes-tehnologii.

3. Blinov, A. O. (Ed.). (2010). Reinzhiniring biznes-protsessov. M.: YuNITI-DANA.

4. Brimson, D. A. (2007). Strategiya reinzhiniringa. Menedzhment I Menedzher, (5), 4-10.

5. Andersen, B. (2003). Biznes protsessyi. Instrumentyi sovershenstvovaniya (S. V. Arinicheva, Trans.; Yu. P. Adler, Ed.). M.: RIA «Standartyi i kachestvo».

6. Robson, M., \& Ullah, F. (1997). Prakticheskoe rukovodstvo po reinzhiniringu biznes protsessov (N. D. Eriashvili, Ed.). M.: Audit, YuNITI.

7. Antikrizisnyiy menedzhment: Trening-seminar. - Proekt UKR/96/007 «Podderzhka razvitiya malyih i srednih predpriyatiy v Ukraine». (1999). In Mezhdunarodnyiy Tsentr Razvitiya Predprinimatelstva i Menedzhmenta, Gosudarstvennyiy komitet Ukrainyi po Razvitiyu Predprinimatelstva, - Programa razvitiya Organizitsii Obedinennyih Natsiy. Poltava.

8. Vynohradova, O. (2005). Osoblyvosti modeliuvannia biznes-protsesiv orhanizatsii na pryntsypakh reinzhynirynhu. Visnyk Ternopilskoi Akademii Narodnoho Hospodarstva, (2), 263-270.

9. Konspekt modeli upravleniya kachestvom. (2002). K.: Ukrainskaya assotsiatsiya kachestva. Mezhotraslevoy tsentr kachestva «Prirost».

10. 7 Not menedzhmenta : Nastolnaya kniga rukovoditelya. (2007). M.: EKSMO.

11. Systema upravlinnia yakistiu. Vymohy (ISO 9001 : 2008, IDT): DSTU ISO 9001:2009 (pp. 1-34). (2010). Derzhstandart Ukrainy.

Received 2 March 2018

Approved 16 March 2018 Available in Internet 7.07.2018 